\title{
STATE LAW HOLOCAUST-ERA ART CLAIMS AND FEDERAL EXECUTIVE POWER
}

Doctrines of judicial restraint in international cases take many forms, but they all have at their heart a concern about the proper role of courts, be they federal or state. This Article explores the proper role of courts in deciding state law conversion claims for art stolen or subject to forced or duress sale during the Nazi era. Many presume, incorrectly, that such claims must be precluded by separation of powers and federalism doctrines. This Article demonstrates the inaccuracy of such presumptions.

Holocaust-era claims lie at the intersection of separation of powers and federalism doctrines, neither of which restricts the courts in this context. To explain, it is necessary to cover quite a bit of doctrine. Thus, this Article is divided into the following parts. Part I discusses the general roles of the executive, legislative, and judicial branches of the federal government, as well as state versus federal government, in regard to foreign affairshistorically and in today's globalized world. Part II specifically addresses Holocaust-era art claims by offering the history essential to understanding the Holocaust-era art problem. Part III discusses the role of judicial restitution in the United States in augmenting executive policy to restitute Holocaust-era art, regardless of whether claims are filed in federal or state courts. Part IV, with a special emphasis on one particularly problematic Ninth Circuit case, Von Saher v. Norton Simon Museum of Art at Pasade$n a,{ }^{1}$ analyzes how courts, seemingly out of a misguided attempt to avoid intruding on foreign affairs, are misapplying state law time-bar and other technical doctrines in Holocaust-art litigation. In light of the emphasis in this Article on judicial restitution failures, Part V discusses present legal efforts to restore power to claimants seeking restitution of Holocaust-era art. Part VI concludes that it is essential for the Supreme Court to correct the judicial errors and reclaim the judicial role in Holocaust-era art restitution. If it fails to do so, neither Congress nor the executive branch is likely to come to the rescue given the present crises, which now absorb those branches' attention.

\footnotetext{
Professor of Law, Northern Kentucky University Chase College of Law.

1592 F.3d 954 (9th Cir. 2010) (link).
} 


\section{GOVERNMENTAL ROLES - HISTORICALLY AND TODAY}

The executive branch of the federal government is the primary actor in waging war, ${ }^{2}$ including post-war criminal prosecutions and reparations, and foreign affairs generally. ${ }^{3}$ Congress, the other political branch, also has a role when it comes to war and foreign affairs, though smaller than the executive. $^{4}$ The judiciary, however, has traditionally refrained from weighing in on foreign policy. In 1918, the Supreme Court distinguished the two political branches from the judiciary in Oetjen v. Central Leather Co. ${ }^{5}$ and held that in matters of foreign affairs, "the propriety of what may be done in the exercise of this political power is not subject to judicial inquiry or decision." $"$

The Court's early pronouncements denied the states any role in foreign relations. In 1941, the Court stated, "Our system of government is such that the interest of the cities, counties and states, no less than the interest of the people of the whole nation, imperatively requires that federal power in the field affecting foreign relations be left entirely free from local interference."

Nevertheless, today federal and state courts and legislatures frequently make decisions that potentially or actually impact foreign relations. ${ }^{8}$ Sometimes, their decisions go too far and disrupt the federal executive branch's power and responsibility to speak with one voice for the nation. For example, when the Supreme Court struck down a Massachusetts statute that prohibited Massachusetts government contractors from buying materials from

2 See Am. Ins. Ass'n v. Garamendi, 539 U.S. 396, 415 (2003) (citing Sale v. Haitian Ctrs. Council, Inc., 509 U.S. 155, 188 (1993)) (“[T]he President has 'unique responsibility' for the conduct of 'foreign and military affairs.”') (link); Ex parte Quirin, 317 U.S. 1, 26-27 (1942) (link).

3 See Hamdi v. Rumsfeld, 542 U.S. 507, 531 (2004) (link); First Nat'l City Bank v. Banco Nacional de Cuba, 406 U.S. 759, 766 (1972) (link); Iwanowa v. Ford Motor Co., 67 F. Supp. 2d 424, 485 (D.N.J. 1999) ("The executive branch has always addressed claims for reparations as claims between governments.") (link).

4 See, e.g., United States v. Curtiss-Wright Exp. Corp., 299 U.S. 304, 319-20 (1936) (link).

5246 U.S. 297 (1918) (link).

${ }^{6}$ Id. at 302; accord Chi. \& S. Air Lines, Inc. v. Waterman S.S. Corp., 333 U.S. 103, 111 (1948) ("It would be intolerable that courts, without the relevant information, should review and perhaps nullify actions of the Executive taken on information properly held secret. Nor can courts sit in camera in order to be taken into executive confidences.") (link).

7 Hines v. Davidowitz, 312 U.S. 52, 63 (1941) (link); accord The Chinese Exclusion Case, 130 U.S. 581, 605-06 (1889) (link).

8 See, e.g., Samantar v. Yousuf, 130 S. Ct. 2278, 2292-93 (2010) (holding that high-ranking governmental individuals sued for torture-related claims are not entitled to foreign sovereign immunity) (link); Sosa v. Alvarez-Machain, 542 U.S. 692, 697, 738 (2004) (dismissing claims under the Federal Tort Claims Act brought by an individual kidnapped in Mexico and brought into the United States to face criminal charges for torturing and murdering a Drug Enforcement Agency agent) (link); Rasul v. Bush, 542 U.S. 466, 484 (2004) (holding that Guantanamo Bay detainees had habeas corpus rights) (link); Argentine Republic v. Amerada Hess Shipping Corp., 488 U.S. 428, 431, 443 (1989) (holding there was no jurisdiction to hear claim of Liberian corporation against Argentina for sinking of its oil tanker during time of war) (link). 


\section{NORTHWESTERN UNIVERSITY LAW REVIEW COLLOQUY}

Burma, it stated that "the 'nuances' of 'the foreign policy of the United States ... are much more [i.e., not exclusively] the province of the Executive Branch and Congress than of this Court."'9 The Court has recently claimed some judicial power implicating foreign affairs for the judiciary. For example, in Hamdi v. Rumsfeld, the Court proclaimed its power to check the political branches, even in times of war. ${ }^{10}$

In today's globalized world, where governments often act as private actors and individual rights are increasingly superseding old conceptions of sovereignty, ${ }^{11}$ modern interpretation of judicial deference doctrines control. $^{12}$ The act of state doctrine provides a poignant example. Whereas courts had been using the doctrine "to avoid deciding difficult cases," Supreme Court in 1990 in W.S. Kirkpatrick \& Co. v. Environmental Tectonics Corp. cautioned against "expansion" of the doctrine and stated: "The short of the matter is this: Courts in the United States have the power, and ordinarily the obligation, to decide cases and controversies properly presented to them." ${ }^{14}$ Thus, although the political branches dominate foreign affairs, under recent Supreme Court precedent a court may not shirk its constitutional responsibility just because the executive branch may bristle at its ruling. ${ }^{15}$

\section{Minimal HolocaUST-ERA ART BACKGROUND}

Some minimum background is essential to understand the point of this Article, that federal and state courts must exercise jurisdiction to fulfill their duties and obligations to resolve cases and controversies surrounding art that was stolen or sold in forced or duress conditions during World War II. It is commonly estimated not only that the Nazis stole twenty percent of all Western art in Europe but also that at least 100,000 pieces are still miss-

\footnotetext{
${ }^{9}$ Crosby v. Nat'l Foreign Trade Council, 530 U.S. 363, 386 (2000) (quoting Container Corp. of Am. v. Franchise Tax Bd., 463 U.S. 159, 196 (1983)) (link).

${ }^{10} 542$ U.S. 507, 509 (2004) ("We hold that although Congress authorized the detention of combatants ..., due process demands ... a meaningful opportunity to contest the factual basis for that detention before a neutral decisionmaker.") (O’Connor, J., plurality opinion).

11 See, e.g., Andrew D. Patterson, The Act of State Doctrine is Alive and Well: Why Critics of the Doctrine are Wrong, 15 U.C. DAVIS J. INT'L L. \& POL'Y 111, 120 (2008) (“The move towards freer scrutiny of state actions is best explainable by the drastic changes in international law and foreign affairs that occurred in the decades between Underhill and Sabbatino.").

12 See Banco Nacional de Cuba v. Sabbatino, 376 U.S. 398, 428 (1964) (holding that application of the act of state doctrine applies as to a "foreign sovereign government, extant and recognized by this country at the time of suit") (link); see also Republic of Austria v. Altmann, 541 U.S. 677, 701-02 (2004) (applying the Foreign Sovereign Immunities Act (the FSIA) to expropriation pre-dating passage of the FSIA) (link).

13 Michael J. Bazyler, Abolishing the Act of State Doctrine, 134 U. PA. L. REV. 325, 353 (1986).

14493 U.S. 400, 409 (1991) (9-0 decision, Scalia, J.) (emphasis added) (link).

15 See Bazyler, supra note 13, at 383-84.
} 
ing. ${ }^{16}$ The United States and its allies during World War II initially committed to reversing Aryanizations, ${ }^{17}$ forced sales, and duress sales via restitution of "readily identifiable works" directly to theft victims. ${ }^{18}$ As the Cold War set in and the Allies implemented the Marshall Plan, however, other issues were prioritized over direct restitution. ${ }^{19}$ Thereafter, artworks were returned to the nations from which they were taken; those nations were then expected to restitute the artworks to victims and their families, but many pieces were not restituted to their previous owners. ${ }^{20}$ A number of nations established post-War claims tribunals, but they were not widely successful in achieving justice. ${ }^{21}$ In order for victims to claim property, they needed to come forward with whatever scraps of evidence they could find in an era of destruction, closed archives, strict privacy laws, persistent anti-Semitism, Cold War lines, and no Internet. ${ }^{22}$

16 Judy Dempsey, Roadblocks Remain in Case of Paintings Lost to Nazis, N.Y. TIMES, Oct. 28, 2010, http://www.nytimes.com/2010/10/29/arts/29iht-loot.html?_r=1 (link) (noting that twenty percent of all Western art in Europe was looted during World War II); John R. Crook, Brief Notes, 105 AM. J. INT'L L. 160, 161 (2011) (The United States actively participates in the Task Force for International Cooperation on Holocaust Education, Remembrance, and Research, which reports that "an estimated 650,000 artworks were confiscated by the Nazis in occupied Europe, including works by Pablo Picasso, Vincent [v]an Gogh, Salvador Dali and Claude Monet. Furthermore, it is estimated that between 100,000 to 200,000 works are still missing) (citing Online Database of Stolen Artworks Launched, THE TASK FORCE FOR INTERNATIONAL COOPERATION ON HOLOCAUST EDUCATION, REMEMBRANCE, AND RESEARCH, Oct. 21, 2010, http://www.holocausttaskforce.org/news/234-online-database-of-stolenartworks-launched.html)).

17 Avraham Barkai, Arisierung, 1 ENCYCLOPEDIA OF THE HOLOCAUST 84 (Israel Gutman ed., 1990) ("[T]erm used to denote the transfer of Jewish-owned independent economic enterprises to 'Aryan' German ownership throughout the Third Reich and the countries it occupied.").

18 Von Saher v. Norton Simon Museum of Art at Pasadena, 592 F.3d 954, 957-58 (9th Cir. 2010) (citing Presidential Advisory Commission on Holocaust Assets in the United States, Plunder And Restitution: THE U.S. And Holocaust Victims’'AsSETS SR-142 (2000)).

19 Michael J. Kurtz, Resolving a Dilemma: The Inheritance of Jewish Property, 20 CARDOZO L. REV. 625, 626 (1998) ("Though the commitment to restore cultural property was supposedly absolute and unconditional, the political failure of the Allied Control Council ('ACC') in Germany and the onset of the Cold War in Eastern Europe raised significant barriers to a successful cultural restitution effort."); cf. Raymond Vernon, The World Trade Organization: A New Stage in International Trade and Development, 36 HARV. INT'L L.J. 329, 330 (1995) (describing how a 1948 draft agreement for the International Trade Organization languished as "the Cold War grew more frigid, the Marshall Plan was launched, and the Korean War erupted").

${ }^{20}$ See, e.g., Von Saher, 592 F.3d at 958 (describing evolution from direct restitution to external restitution and how "[d]espite these restitution efforts, many paintings stolen by the Nazis were never returned to their rightful owners.”) (citing MiChaEl J. BAZYLER, HOlOCAUST JustiCE: THE BATTLE FOR RESTITUTION IN AMERICA's COURTS 204 (2003)).

21 E.g., id.; see also Benjamin Ferencz, From Nuremberg to Rome: A Personal Account, in JUSTICE FOR CRIMES AgAinst HuMANITY 37, 38 (Mark Lattimer \& Philippe Sands eds., 2003) ("When the restitution and indemnification laws were enacted, every claim had to be verified by a complex administrative apparatus that put a strict burden of proof on every claimant.").

22 See, e.g., Brian F. Havel, In Search of a Theory of Public Memory: The State, the Individual, and Marcel Proust, 80 IND. L.J. 605, 648 (2005) (describing post-War anti-Semitism in Austria); Kurtz, supra note 19, at 632; Inga Markovits, Selective Memory: How the Law Affects What We Remember and 


\section{NORTHWESTERN UNIVERSITY LAW REVIEW COLLOQUY}

Injustice pervaded post-War restitution. France simply incorporated Jewish-owned artworks into the collection of the Louvre without ever attempting to return them to the victims and their families. ${ }^{23}$ In Austria, victims seeking restitution of artworks were forced to make donations of other property in exchange for the necessary export permits to take the artworks to their new homelands. ${ }^{24}$ Renewed public attention to such scandals in the mid-to-late 1990s strengthened U.S. resolve to effectuate its War-era promises through means that included use of the courts to resolve state law claims.

\section{JUDICIAL RESTITUTION IN THE UNITED STATES}

Judicial restitution has played a key role in implementing executive policy to restitute property stolen from Jews within the Third Reich and Nazi-occupied territory. This Part illuminates that role by first discussing the act of state doctrine and how its proper construction should not operate as a bar against judicial restitution of Holocaust-era art. Then, this Part will discuss modern-era Holocaust litigation and diplomatic developments intended to support judicial restitution of Holocaust-era art.

\section{A. The Act of State Doctrine Is No Bar to Judicial Restitution}

Nazi confiscation and expropriation, official governmental taking of property with or without compensation, occurred pursuant to the Nuremberg Laws and other official governmental decrees. ${ }^{25}$ Generally, under the act of state doctrine, the courts of one sovereign do not question the acts of

Forget About the Past-The Case of East Germany, 35 L. \& Soc'Y REV. 513, 519 (2001) (describing post-War anti-Semitism in East and West Germany); Thérèse O'Donnell, The Restitution of Holocaust Looted Art and Transitional Justice: The Perfect Storm of the Raft of the Medusa?, 22 EUR. J. INT'L L. 49, 65 (2011) (describing how difficult research into an artwork's location was prior to the Internet); Collin McDonald, Note, Reconciling Holocaust Scholarship and Personal Data Protection: Facilitating Access to the International Tracing Service Archive, 30 FordHAM INT'L L.J. 1360, 1384 (2007) (“[T]he effort to enact a rigorous data protection scheme might be better understood [as] an attempt to prevent additional harm befalling those who already suffered in the Holocaust ....") (link); Leah J. Weiss, Note, The Role of Museums in Sustaining the Illicit Trade in Cultural Property, 25 CARDOZO ARTS \& ENT. L.J. 837, 866-67 (2007) (describing post-War difficulties for claims overall) (link).

23 See Hector Feliciano, The Lost Museum: The Nazi Conspiracy to Steal the World's GREATEST WORKS OF ART 218-19, 235-36 (1997).

24 See, e.g., Republic of Austria v. Altmann, 541 U.S. 677, 684 (2004) (acknowledging that there were individuals in Austria who "had been coerced into donating artworks to state museums in exchange for export permits").

25 See, e.g., Martin Dean, Robbing the Jews: The Confiscation of JeWish Property in the HoLOCAUST, 1933-1945 (2008) (describing systematic expropriation of Jews' property under Nuremberg laws and otherwise); GÖTZ ALY, HitLER's BENEFICIARIES: PLUNDER, RACIAL WAR, AND THE NAZI WELFARE STATE (2005) 184-86 (describing how the Nazis systematically expropriated Jewish property in occupied countries). 
another sovereign acting in its sovereign capacity. ${ }^{26}$ The doctrine applies "to a case involving the title to property brought within the custody of a court, ... . for [the doctrine] rests at last upon the highest considerations of international comity and expediency." 27

The act of state doctrine, however, does not apply to the Nazi regime because it was a criminal organization. ${ }^{28}$ In an April 1949 letter, Jack B. Tate, U.S. Department of State Acting Legal Adviser, clarified executive policy concerning judicial restitution of Nazi-era despoiled property, at least insofar as the act of state doctrine was concerned. ${ }^{29}$ The letter relayed the following:
[I]t is this Government's policy to undo the forced transfers and restitute identifiable property to the victims of Nazi persecution wrongfully deprived of such property; and ... the policy of the Executive, with respect to claims asserted in the United States for restitution of such proper- ty, is to relieve American courts from any restraint upon the exercise of their jurisdiction to pass upon the validity of the acts of Nazi officials. ${ }^{30}$

Courts, however, have wrangled with the act of state doctrine and the importance of State Department positions. ${ }^{31}$ The Supreme Court in 1964

26 See W.S. Kirkpatrick \& Co. v. Envtl. Tectonics Corp., Int'1, 493 U.S. 400, 409 (1990); Banco Nacional de Cuba v. Sabbatino, 376 U.S. 398, 423 (1964); Underhill v. Hernandez, 168 U.S. 250, 252 (1897) (link).

27 Oetjen v. Cent. Leather Co., 246 U.S. 297, 303-04 (1918).

28 See Bernstein v. N.V. Nederlandsche-Amerikaansche Stoomvaart-Maatschappij, 210 F.2d 375, 376 (2d Cir. 1954) (per curiam) (link); see also First Nat'l City Bank v. Banco Nacional de Cuba, 406 U.S. 759, 789 n.n.12 \& 13 (1972) (Brennan, J., dissenting) (criticizing the Bernstein exception yet acknowledging the argument for targeted exception for the Nazi regime in conversion cases) (link). But see Westfield v. Germany, 633 F.3d 409, 418 (6th Cir. 2011) (finding a lack of jurisdiction under the Foreign Sovereign Immunity Act to sue Germany for Nazi-era taking).

29 Bernstein, 210 F.2d at 376 (discussing Tate Letter). The State Department expressly delineated its position, albeit not in the context of a particular case, when renowned Fine Arts \& Monuments Adviser Ardelia R. Hall published in the State Department Bulletin on August 27, 1951: "For the first time in history, restitution may be expected to continue for as long as works of art known to have been plundered during a war continue to be rediscovered." Ardelia R. Hall, The Recovery of Cultural Objects Dispersed During World War II, 25 DeP'T ST. Bull. 337, 339 (1951).

30 Bernstein, 210 F.2d at 376 (quoting Press Release No. 296, U.S. Dept. of State, Jurisdiction of United States Courts Re Suits for Identifiable Property Involved in Nazi Forced Transfers (Apr. 27, 1949)).

31 See generally Derek Baxter, Protecting the Power Of The Judiciary: Why the Use of State Department "Statements of Interest" in Alien Tort Statute Litigation Runs Afoul of Separation of Powers Concerns, 37 Rutgers L.J. 807, 833-34 (2006) (link); Michael J. Bazyler, Abolishing the Act of State Doctrine, supra note 13, at 330-62 (discussing inconsistent judicial application of the act of state doctrine since its early development); Catherine Henson Curlet, Note, Should a Statement of Interest Matter?: Judging Executive Branch Foreign Policy Concerns, 44 GA. L. REv. 1063 (2010). 
questioned the continuing vitality of the act of state doctrine and noted that the argument for judicial deference is particularly weak "if the government which perpetrated the challenged act of state is no longer in existence." ${ }^{32}$ The Supreme Court in Republic of Austria v. Altmann indicated that the views of the executive branch generally are not entitled to "special deference," but that particularized deference may be warranted if the State Department were to communicate specific foreign policy ramifications of a particular case. ${ }^{33}$ In conclusion, although courts have struggled with the correct application of the act of state doctrine and separation of powers implications arising from deferring to the executive branch, the act of state doctrine in no way restricts judicial power to decide cases that call into question acts of the criminal Nazi regime.

\section{B. Modern-Era Holocaust Litigation \& Diplomatic Developments}

Not all Holocaust-era claims are the same, and the art cases were not subsumed in diplomatic agreements signed after the War or more recently that trumped claims filed in the 1990s. The London Debt Agreement had been signed on February 27, 1953, by twenty nations, including the United States, with the Federal Republic of Germany to suspend payments on external debts, individuals' claims and reparations in deference to the Marshall Plan. ${ }^{34}$ The purpose was to "remove obstacles to normal economic relations." 35 In 1991, the London Debt Agreement was lifted, which led to the modern wave of Holocaust-era litigation in the United States. ${ }^{36}$ By 1995, individual and class actions began to be filed in the United States against European nations and entities seeking compensation for such things as unpaid insurance policies, unrestituted bank accounts, and slave and forced labor. ${ }^{37}$ President Clinton entered into a series of executive agreements whereby the United States would file "statements of interest" in pending cases. ${ }^{38}$ A statement of interest is a non-binding document that expresses the State Department's position in a case. ${ }^{39}$ The statements of inter-

\footnotetext{
32 Banco Nacional de Cuba v. Sabbatino, 376 U.S. 398, 428 (1964).

33 Republic of Austria v. Altmann, 541 U.S. 677, 701-02 (2004). In fact, the Foreign Sovereign Immunities Act seeks to eliminate political motivation from judicial jurisdictional determinations. See, e.g., Sigmund Timberg, Sovereign Immunity and Act of State Defenses: Transnational Boycotts and Economic Coercion, 55 TEX. L. REV. 1, 11 (1976).

34 Agreement on German External Debts, Feb. 27, 1953, 4 U.S.T. 443, 333 U.N.T.S. 3 (the London Debt Agreement).

35 Id. at Preamble.

36 See, e.g., Michael J. Bazyler, Nuremberg in America: Litigating the Holocaust in United States Courts, 34 U. Rich. L. REV. 1, 217 (2000).

37 See e.g., Am. Ins. Ass'n v. Garamendi, 539 U.S. 396, 403-05 (2003) (discussing Agreement on German External Debts, supra note 34, 4 U.S.T. at 449); Burt Neuborne, Preliminary Reflections on Aspects of Holocaust-Era Litigation in American Courts, 80 WASH. U. L. Q. 795, 813-16 (2002).

38 See, e.g., Bazyler, supra note 36, at 202 n.817.

${ }^{39} C f$. Republic of Austria v. Altmann, 541 U.S. 677, 701-02 (2003) (describing statements of interest generally).
} 
est promised in the Holocaust cases were to (and did) express the view that it was in the foreign policy interests of the United States to dismiss the cases on "any valid legal grounds" to achieve "legal peace" for the European defendants,$^{40}$ which it was hoped would lead to the return of normal diplomatic relations. In exchange, new foundations were established throughout Europe that would consider individual claims and award compensation. ${ }^{41}$ Claims to art, however, were excluded from the Clinton-era agreements, presumably because the value of the claims would have dwarfed the other claims and there is a great disparity in valuation of the art, much of which could not be located. ${ }^{42}$

Art became a focus of post-Cold War diplomatic negotiations in 1998 when the United States hosted the Washington Conference and garnered the signatures of forty-four nations to the Washington Principles (the Principles). ${ }^{43}$ The non-binding Principles call on nations to facilitate identification of Nazi-looted art and reach "just and fair" solutions. ${ }^{44}$ In 2009, the Terezín Declaration, signed by forty-six nations, reinforced the Principles. ${ }^{45}$ It provides that nations should:

ensure that their legal systems or alternative processes, while taking into account the different legal traditions, facilitate just and fair solutions with regard to Nazi-confiscated and looted art, and ... make certain that claims to recover such art are resolved expeditiously and based on the facts and merits of the claims and all the relevant documents submitted by all parties. ${ }^{46}$

Thus, the United States has an international obligation to provide claimants a means to seek restitution. Unlike a number of other countries, the United States has not yet built a commission to resolve such claims. ${ }^{47}$ Thus, going to court to assert a "garden-variety" state law conversion or replevintype claim remains the only legal mechanism to seek restitution of Holo-

\footnotetext{
40 See Garamendi, 539 U.S. at 406.

41 E.g., Holocaust Restitution: Perspectives on the Litigation and Its Legacy (Michael Bazyler \& Roger P. Alford eds., 2006).

42 Jennifer Anglim Kreder, Reconciling Individual and Group Justice with the Need for Repose in Nazi-Looted Art Disputes, 73 BROOK. L. REV. 155, 165-66 (2007).

43 U.S. State Dep't, Washington Conference Principles on Nazi-Confiscated Art, in WASHINGTON CONFERENCE ON HOLOCAUST-ERA ASSETS PROCEEDINGS 971, 971-72 (1998), available at http://www.state.gov/www/regions/eur/holocaust/heacappen.pdf (link).

44 Id.

45 U.S. DEPT. STATE, TEREZIN DEClaration (June 30, 2009), available at http://www.state.gov/p/eur/rls/or/126162.htm (link).

${ }^{46}$ Id. (emphasis added).

47 E.g., Norman Palmer, Museums and the Holocaust: Law, Principles AND Practice 27, 104 (2000) (discussing the UK Spoliation Advisory Panel and the French commission).
} 
caust-era art in the United States. ${ }^{48}$ As discussed below, the manner in which U.S. courts are dismissing such claims has rendered the United States out of compliance with the very principles it led the world to adopt.

\section{THE FEDERAL-STATE BALANCE IN NAZI-LOOTED ART RESTITUTION}

Unfortunately, the outcome of Holocaust-era art litigation often turns on statutes of limitations and other technical doctrines. This Part will analyze both time-bar and preemption doctrines implicated by such litigation and how courts misapply them, perhaps out of a misplaced deference to incorrect assumptions about federal executive policy.

\section{A. Statutes of Limitations and Other Time-Bar Doctrines}

Under the American common law, it is axiomatic that the title to stolen art does not pass to the new owner except in limited circumstances involving certain bailments. However, time-bar doctrines and other technicalities could bar a claim by the rightful owner. ${ }^{49}$ For example, under the discovery rule, the statute of limitations does not begin to run until the plaintiff discovers the loss and location of his or her stolen property-or should have done so. ${ }^{50}$ Currently, courts are often construing time-bar doctrines in Holocaust art cases in a way that faults survivors and their heirs for waiting too long to seek restitution, even though in most cases it would have been impossible or futile to seek restitution earlier, thereby distorting discovery rule and related jurisprudence. ${ }^{51}$ For example, one federal court in Michigan ruled that the discovery rule was inapplicable, in part because of the policy to encourage the plaintiff "to diligently pursue his claim," and hence the statute of limitations on one German Jew's claim ran in $1938 .{ }^{52}$

Perhaps courts are construing time-bar doctrines to dismiss seemingly meritorious claims out of an unstated and misplaced fear of injecting themselves into foreign affairs. A broad-brush understanding of the class actions filed in the mid-1990s, most of which were dismissed based on various judicial deference doctrines, such as the political question and international comity doctrines, could predispose one to assume that other Holocaust

\footnotetext{
48 E.g., Patricia Youngblood Reyhan, A Chaotic Palette: Conflict of Laws in Litigation Between Original Owners and Good-Faith Purchasers of Stolen Art, 50 DUKE L.J. 955 (2001) (link).

49 See, e.g., Alexandra Minkovich, Note, The Successful Use of Laches in World War II-Era Art Theft Disputes: It's Only a Matter of Time, 27 COLUM. J.L. \& ARTs 349, 349 (2004).

50 E.g., Erisoty v. Rizik, No. Civ. A. 93-6215, 1995 WL 91406, at*10-12 (E.D. Pa. Feb. 23, 1995) (providing overview of discovery rule and other time-bar doctrines).

51 Jennifer Anglim Kreder, Guarding the Historical Record from the Nazi-Era Art Litigation Tumbling Toward the Supreme Court, 159 U. PA. L. REV. PENNUMBRA 253, 260-62 (2011) (link).

52 Detroit Inst. of Arts v. Ullin, No. 06-10333, 2007 WL 1016996, at *3 (E.D. Mich. Mar. 31, 2007).
} 
claims must similarly be dismissed. ${ }^{53}$ Rather than look into the thorny cases, courts seem to be willing to engage in "judicial abdication of their responsibility for resolving international law issues." 54

\section{B. Preemption}

The California state legislature has sought to do something about the judicial misinterpretation of statutes of limitations and discovery rule principles, but judicial trepidation about interfering with foreign affairs seems thus far to have foiled its efforts. The California legislature passed California Civil Procedure Code Section 354.3 in 2002, which extended the statute of limitations for claims seeking restitution from museums and galleries to December 31, 2010.55 As discussed below, California's abandonment of discovery rule principles in favor of a firm statute of limitations for Holocaust-era claims has put the spotlight on the federal-state balance in Holocaust-art restitution, a field that necessarily touches upon foreign affairs.

Earlier Supreme Court case law outside of the Holocaust art context had established that, while there can be "no question that at some point an exercise of state power that touches on foreign relations must yield to the National Government's policy," "even treaties ... will be carefully construed so as not to derogate from the authority and jurisdiction of the States of this nation unless clearly necessary to effectuate the national policy." 57 Thus, the Supreme Court has been careful to preserve state power even if it may touch on foreign relations, although the federal government retains the final word on foreign policy.

53 See, e.g., Freund v. Republic of France, 592 F. Supp. 2d 540, 552, 572-73 (S.D.N.Y. 2008) (dismissing a class action claim for lack of jurisdiction and, alternatively, on political question and international comity grounds and noting that 'a 'lack of respect' to the Executive Branch would result if the Court were to disregard the Executive's declared preference . . . to resolve these claims 'outside of litigation."') (link).

54 See Bazyler, supra note 13, at 383 (discussing the doctrine generally) (internal quotation omitted); accord, e.g., Frank Walsh, Flipping the Act of State Presumption: Protecting America's International Investors from Foreign Nationalization Programs, 12 TEX. REV. L. \& POL. 369, 381-91 (2008) (discussing "muddled jurisprudence" of the act of state doctrine since Sabbatino).

55 CAL. Civ. Proc. CODE $\S 354.3$ (c) (West 2006) (link). California has passed other legislation concerning Holocaust claims and claims arising out of the Armenian genocide, all of which have been challenged in courts. See Am. Ins. Ass'n v. Garamendi, 539 U.S. 396, 401 (2003) (finding unconstitutional California's Holocaust Victim Insurance Relief Act of 1999); Deutsch v. Turner Corp., 324 F.3d 692, 703 (9th Cir. 2003) (holding unconstitutional a California statute creating a cause of action for claims involving Second World War slave labor) (link). But see Movsesian v. Victoria Versicherung AG, 629 F.3d 901, 903 (9th Cir. 2010) (2-1 opinion) (upholding legislation extending statute of limitations for Armenian genocide claims and replacing earlier opinion holding the opposite) (link). It is virtually impossible to reconcile Movsesian and Alperin v. Vatican Bank, 410 F.3d 532 (9th Cir. 2005) (link), discussed below, with Von Saher and Deirmenjian v. Deutsche Bank, A.G., 526 F. Supp. 2d 1068, 1085 (C.D. Cal. 2007) (holding that Armenian genocide property claims are preempted) (link).

56 Garamendi, 539 U.S. at 413 (citing Banco Nacional de Cuba v. Sabbatino, 376 U.S. 398, 427 n.25 (1964)).

57 United States v. Pink, 315 U.S. 203, 230 (1942) (link). 


\section{NORTHWESTERN UNIVERSITY LAW REVIEW COLLOQUY}

The federal-state balance was disrupted in Von Saher v. Norton Simon Museum of Art at Pasadena ${ }^{58}$ when the Ninth Circuit misapplied the preemption doctrine. The two-judge majority completely misconstrued executive involvement in art recovery ${ }^{59}$ to conclude, without support, that in light of executive war-era efforts to restitute art and its decision to implement the Marshall Plan, "[i]t is beyond dispute that there was no role for individual states to play in the restitution of Nazi-looted assets during and immediately following the war."60

The panel incorrectly interpreted the significance of executive efforts; the executive never expressed an intent to displace judicial restitution as an option available to survivors seeking to recover their art. In fact, since the War, survivors and heirs have filed successful claims in federal and state courts to recover art and other property. ${ }^{61}$ The State Department Special Envoy for Holocaust Issues specifically recognized that the U.S. Government has a limited role in cases involving claimants and private institutions. $^{62}$ The State Department has never had any intention of shutting down courts as an avenue of restitution. Nor did the California legislature open courts up for the first time. The legislation simply tried to prevent courts from misapplying discovery rule doctrines to dismiss cases that should not be dismissed. In other words, Section 354.3 seeks to make California's proplaintiff time-bar policy clearer. This is proper because there has never been a federal effort to preempt state authority on the matter.

The Von Saher majority relied on American Insurance Ass'n v. Garamendi, a Supreme Court case that struck down California's Holocaust Victim Insurance Relief Act (the HVIRA) under the foreign affairs field preemption doctrine. ${ }^{63}$ The HVIRA required insurance companies operating in the state to disclose information about policies they or their affiliates wrote in Europe between 1920 and 1945, even if such disclosure was not under the insurance company's direct control and such disclosure was prohibited by European privacy laws. ${ }^{64}$

The Clinton-era executive agreements provided that the United States would file statements of interest in Holocaust-era claims capable of resolu-

58592 F.3d 954 (9th Cir. 2010).

59 Id. at $961-63$.

60 Id. at 967.

61 See, e.g., Kunstsammlungen zu Weimar v. Elicofon, 478 F.2d 231 (2d Cir. 1973); Bernstein v. N.V. Nederlandsche-Amerikaansche Stoomvaart-Maatschappij, 210 F.2d 375 (2d Cir. 1954) (per curiam); Menzel v. List, 246 N.E.2d 742 (N.Y. 1969).

62 J. Christian Kennedy, Special Envoy for Holocaust Issues, Remarks at University of Potsdam Conference (April 23, 2007), available at http://germany.usembassy.gov/kennedy_speech.html ("Because art claims in the United States have generally had a claimant on one side and a private institution or individual collector on the other, the role of the U.S. Government has been limited on specific cases.") (link).

63 See Am. Ins. Ass'n v. Garamendi, 539 U.S. 396, 401 (2003).

64 Holocaust Victim Insurance Relief Act (HVIRA) of 1999, CAL. Ins. CoDE $\S \S 13800-07$ (West 2006). 
tion in the newly created European foundations. ${ }^{65}$ Insurance claims were to be resolved on a voluntary basis by the International Commission on Holocaust Era Insurance Claims (the ICHEIC) after insurance companies provided whatever documentation they could find related to the claims. ${ }^{66}$ Even though none of the executive agreements or supporting documents specifically addressed disclosure of insurance policy information, the Garamendi majority held by a five-to-four margin that the California statute interfered with foreign affairs policy objectives implicit in the executive agreements. ${ }^{67}$

The Von Saher majority applied Garamendi with an extremely broad brush and concluded that the California legislation was preempted by executive war-era restitution efforts and Clinton-era executive agreements. ${ }^{68}$ In effect, the panel ruled that even though state law may provide for a generalized conversion claim with regard to stolen art, a state is powerless to refine its statute of limitations as to Holocaust-specific restitution claims.

A correct interpretation of Garamendi would have recognized that a state does have the power to refine its statute of limitations to prevent its courts from misapplying fluid discovery rule and time-bar principles in Holocaust-era art cases. Focusing on Justice Harlan's concurrence in Zschernig $v$. Miller, the only other Supreme Court case to find that executive policy short of a treaty preempted state law, illustrates why. Justice Harlan pointed out that, absent a direct conflict between state law and executive policy, "the States may legislate in areas of their traditional competence even though their statutes may have an incidental effect on foreign relations." 69 California's Section 354.3 concerns the statute of limitations on common law property claims, certainly an area of traditional state competence. Arguments about its effect on foreign affairs are likely overblown, as common law Holocaust-era claims may be brought in any state and are subject to the flexible discovery rule-type doctrines that normally apply. For example, the United States District Court for the Southern District of New York recently ruled that a claim for a rare book stolen during the War was not barred because the claimant mistakenly, yet reasonably, believed the book had been destroyed during the War. ${ }^{70}$

Section 354.3 is far narrower than the HVIRA, which the Supreme Court concluded was preempted because "California [sought] to use an iron

65 Garamendi, 539 U.S. at 405-06.

66 Id. at 406-07.

${ }^{67}$ Id. at $420-25,430$.

68 Id. at 413-29.

69 Zschernig v. Miller, 389 U.S. 429, 459 (Harlan, J., concurring in result) (link); see also id. at 462 (White, J., dissenting) (agreeing with Justice Harlan that the challenged statute was not "an impermissible interference with foreign affairs").

70 E.g., Sotheby's, Inc. v. Shene, No. 04 Civ. 10067, 2009 WL 762697, at *4 (S.D.N.Y. Mar. 23, 2009) (holding that a sixty-year delay was not unreasonable because the claimant erroneously yet reasonably believed the book was destroyed during the War). 
fist where the President has consistently chosen kid gloves."71 The HVIRA also expressly stated that it applied to European affiliates of in-state companies, over which California would have had no personal jurisdiction. ${ }^{72}$ In contrast, Section 354.3 makes no such extravagant jurisdictional claims; thus, it will apply only to those entities over which California has personal jurisdiction. In fact, the Norton Simon Museum of Pasadena, the defendant in Von Saher, and the art in question are physically located in California; the facts of the case pose absolutely no extravagant personal jurisdiction issues.

Thus, Garamendi does not dictate the result in Von Saher and the Supreme Court should correct judicial misinterpretation of state and judicial power when it comes to Holocaust-era art claims. When judges, in the absence of an applicable executive agreement, construe executive policy so broadly so as to preempt conversion claims as to Holocaust-era art, they are acting as "the expositors of the Nation's foreign policy ... when the President himself has not taken a clear stand." $" 73$ Justice Ginsburg stated in the Garamendi dissent, "As I see it, courts step out of their proper role when they rely on no legislative or even executive text, but only on inference and implication, to preempt state laws on foreign affairs grounds." 74

The Von Saher majority incorrectly concluded that the California legislature created a "world-wide forum for the resolution of Holocaust restitution claims" 75 and thus could assert "no serious claim to be addressing a traditional state responsibility." The majority erred in concluding that the statute "intrudes on the power to make and resolve war." 77 Even though former enemies were not targets - the defendant was an in-state museumthe court held that "the actionable injury at the heart of the statute is the Nazi theft of art," wartime wrongs committed by our enemies or by parties operating under our enemies' protection." ${ }^{79}$ For all of the reasons stated above, the Von Saher majority painted the scope of federal restitution efforts far too broadly, thus deferring to an erroneous interpretation of the significance of executive action for foreign affairs. By refusing to reach the merits of the claim, the court was making its own decision, unsupported by any federal interest, that the claim was not worthy of judicial resolution. In other words, to turn

\footnotetext{
71 Garamendi, 539 U.S.at 427.

72 See id. at 409-10.

73 Id. at $442-43$.

74 Id. at 443.

75 Von Saher v. Norton Simon Museum of Art at Pasadena, 592 F.3d 954, 965 (9th Cir. 2010).

76 Id. (quoting Garamendi, 539 U.S. at 419 n.11 (Ginsburg, J., dissenting)) (internal quotation marks omitted).

77 Id. at $965-66$.

78 Id. at 966.

79 Id. (quoting Deutsch v. Turner Corp, 324 F.3d 692, 708 (9th Cir. 2003)) (internal quotation marks omitted) (discussing special tort actions for slave and forced labor claims).
} 
a blind eye and feign not to decide is to decide. ${ }^{80}$ The Von Saher court thereby engaged in improper policymaking.

The Von Saher majority also ignored the fact that in Republic of Austria v. Altmann, a California case that ultimately resulted in Austria restituting over $\$ 300$ million worth of Holocaust-era art, ${ }^{81}$ the Supreme Court passed up an easy opportunity to shut down a claim on preemption grounds. The Court decided that the Foreign Sovereign Immunities Act (the FSIA), the only means to acquire jurisdiction over a foreign sovereign in U.S. courts, provided for jurisdiction over Austria. ${ }^{82}$ Moreover, the United States did not file a statement of interest in Altmann, which would have encouraged the court to dismiss the case "on any legal ground." 83 Instead, it filed an amicus brief on the narrow issue of FSIA interpretation. ${ }^{84}$

Additionally, the Von Saher majority opinion unsuccessfully distinguished art restitution from the property restitution sought in Alperin v. Vatican Bank. In Alperin, another split Ninth Circuit panel authorized pursuit of "garden-variety property" state law claims against the Vatican for allegedly accepting property from the genocidal, Holocaust-era Croatian Ustasha regime, while finding slave and forced labor claims preempted under the executive preemption doctrine. ${ }^{85}$ In rejecting an argument that the political question doctrine prohibited judicial resolution of the claim, the Alperin court noted that "[r]eparation for stealing, even during wartime, is not a claim that finds textual commitment in the Constitution [to the federal executive branch]." ${ }^{86}$ Thus, a court would have power to award restitution or money damages for such stolen property. ${ }^{87}$ In contrast, the Von Saher majority simply rejected without support the "garden-variety property" characterization of suits seeking restitution of property converted during a time of war. ${ }^{88}$ There is no reason to welcome Croatian war-era state law property claims into court while closing the door on Holocaust-era art claims.

${ }^{80}$ Cf. Ricaud v. Am. Metal Co., 246 U.S. 304, 309 (1918) (holding that upholding a foreign act of state "is not a surrender or abandonment of jurisdiction but is an exercise of it").

81 Diane Haithman, Coming and Going, L.A. TIMES, Dec. 24, 2006, http://articles.latimes.com/2006/dec/24/entertainment/ca-artsyear24 (link).

82 See Republic of Austria v. Altmann, 541 U.S. 677, 700 (2003) (emphasizing the narrowness of its holding); $c f$. Gross v. German Found. Indus. Initiative, 456 F.3d 363, 376 (3d Cir. 2006) (citing Baker v. Carr, 369 U.S. 186, 198 (1962)) (“[A] court with jurisdiction over a claim should nonetheless decline to adjudicate it if it is not justiciable.") (link).

83 See supra note 40 and accompanying text.

${ }^{84}$ Brief for the United States as Amicus Curiae Supporting Petitioners, Republic of Austria v. Altmann, 541 U.S. 677 (2003) (No. 03-13).

85 Alperin v. Vatican Bank, 410 F.3d 532, 562 (9th Cir. 2005) (including claims for "conversion, unjust enrichment, restitution, and an accounting").

86 Id. at 551.

87 See id.

88 Von Saher v. Norton Simon Museum of Art at Pasadena, 592 F.3d 954, 966-67 (9th Cir. 2010). 


\section{NORTHWESTERN UNIVERSITY LAW REVIEW COLLOQUY}

It is possible that the executive branch will remain silent or even appear in Von Saher to encourage dismissal, which would contravene the 1998 Washington Principles and 2009 Terezín Declaration, in which the United States committed to providing for restitution of Holocaust-era art. Such a development would be quite unfortunate, but courts have a constitutional obligation to resolve cases and controversies, even if that means negating the expressed desires of a political branch. ${ }^{89}$ As stated in Baker $v$. Carr, it would be an "error to suppose that every case or controversy which touches foreign relations lies beyond judicial cognizance." $" 90$

Hopefully the Supreme Court will uphold Section 354.3, the California statute at issue in Von Saher. It would be even better, in light of the difficulty Holocaust survivors and heirs have had in discovering their claims before now, if the Supreme Court emphasized the executive branch's support of claims. Such a holding would go a long way toward helping survivors and their heirs circumvent the overly rigid application of time-bar and other technical doctrines. If Von Saher goes unchecked, claimants would be deprived of assistance that state legislatures can provide to clarify time-bar doctrines for Holocaust-era claims.

\section{TRYING TO RESET THE DELICATE BALANCE FOR JUDICIAL RESTITUTION BASED ON STATE LAW}

Efforts to restore prospects for restitution of Holocaust-era art have emerged, but none can succeed unless state law court claims are viable. State law reformers secured new California legislation. On the judicial front, another important California case has surpassed a significant hurdle to proceed against Spain. Additionally, there is a possibility that a commission will be created in the State Department to attempt to resolve Holocaust-era art claims out of court.

\section{A. California Legislative Reform Efforts}

While the petition for certiorari in Von Saher was pending before the Supreme Court, ${ }^{11}$ the California legislature enacted Assembly Bill 2765, which was signed into law by then-Governor Schwarzenegger on August 30, 2010.92 The legislation requires actual discovery (presumably both of the claim and entity to sue) and doubles the length of time allowed between actual discovery and commencement of the cause of action to recover art and other real property from three to six years. ${ }^{93}$ The law would apply to all

\footnotetext{
89 See e.g., Medellin v. Texas, 552 U.S. 491 (2008) (link); Hamdan v. Rumsfeld, 548 U.S. 557 (2006) (link); Republic of Austria v. Altmann, 541 U.S. 677, 691 (2003).

90369 U.S. 186, 211 (1962).

91 The petition is still pending at the time of writing. See Von Saher v. Norton Museum of Art at Pasadena, 592 F.3d 954, appeal docketed, No. 09-1254 (U.S. Apr. 16, 2010) (link).

92 CAL. Civ. Proc. CodE $\S 338$ (West Supp. 2011) (link).

93 Id. at $\S 338(\mathrm{c})(3)(\mathrm{A})$.
} 
new and pending causes of action commenced on or before December 31 , 2017. ${ }^{94}$ It would also include actions that were "dismissed based on the expiration of statutes of limitation in effect prior to the date of enactment" of the bill so long as either the judgment is not yet final or the time for filing an appeal has not yet passed. ${ }^{95}$ The statute also includes a definition of "duress" broader than that implied in any U.S. case to date. ${ }^{96}$

There are limits to the new statute. Present-day possessors of art can still assert legal and equitable defenses, including the statute of limitations (of course) and the equitable defense of laches, which would bar a claim if the plaintiff's unreasonable and inexcusable delay caused defendant prejudice in his or her ability to defend the suit. ${ }^{97}$ Like the earlier California statute, there is no limitation requiring that the museums and galleries sued be located in California, ${ }^{98}$ although they must, of course, be subject to personal jurisdiction there under International Shoe and its progeny.

\section{B. Cassirer v. Kingdom of Spain}

While this state legislation was pending, the Ninth Circuit issued a ruling that permitted another Holocaust-era art suit to go forward. In Cassirer v. Kingdom of Spain, the en banc panel held that Spain and its instrumentality, the Madrid-based Thyssen-Bornemisza Collection Foundation, are subject to jurisdiction under the expropriation exception of the FSIA even though it was the Nazis, not Spain, that engaged in the expropriation. ${ }^{99}$

Cassirer held that the plain language of the expropriation exception, which provides for jurisdiction over claims to property "taken in violation of international law," has no requirement as to who must actually engage in the taking. ${ }^{100}$ The court then found that the Foundation is engaged in sufficient commercial activity in the United States - advertising for tourism-to satisfy the FSIA's commercial activity requirement. ${ }^{101}$ The timeliness of the

$94 I d$. at $\S 338(\mathrm{c})(3)(\mathrm{B})$.

95 Id.

$96 I d$. at $\S 338 \mathrm{c}(3)(\mathrm{C})(\mathrm{iv})$. Duress is defined as "a threat of force, violence, danger, or retribution against an owner of the work of fine art in question, or his or her family member, sufficient to coerce a reasonable person of ordinary susceptibilities to perform an act that otherwise would not have been performed or to acquiesce to an act to which he or she would otherwise not have acquiesced." Id. $C f$. Schoeps v. Museum of Modern Art, 594 F. Supp. 2d 461, 466 (S.D.N.Y. 2009) (stating that under German law "a contract may be declared void [on grounds of duress] if it is entered into when one party is at a distinct disadvantage in bargaining - for example, if that party is in 'dire need' - and its terms lopsidedly favor the other party.") (link). The California standard would not require a finding that the terms were lopsided.

97 See DeWeerth v. Baldinger, 836 F.2d 103, 107 (2d Cir. 1987) (link); Waldman v. 853 St. Nicholas Realty Corp., 882 N.Y.S.2d 481, 483 (App. Div. 2009) (link); Skrodelis v. Norbergs, 707 N.Y.S.2d 197, 198 (App. Div. 2000) (link); Cohen v. Krantz, 643 N.Y.S.2d 612, 614 (App. Div. 1996) (link).

98 See $\$ 338$.

99 616 F.3d 1019, 1028-32 (9th Cir. 2010) (link).

100 Id. at 1031-32.

101 Id. at 1033-34. 
claim was not at issue in the appeal, ${ }^{102}$ but the fact that the Ninth Circuit is allowing the claim to proceed is somewhat in tension with the Von Saher holding that Holocaust-era art claims are preempted. The Supreme Court granted a writ of certiorari in the case and, as it did in Von Saher, asked the Solicitor General to submit a brief explaining the executive branch's views. $^{103}$

\section{A State Department Commission?}

The State Department is currently developing a plan to establish a Nazi-Looted Art Commission, but its mandate would be limited to researching and mediating or arbitrating claims only if both parties agree. ${ }^{104}$ At this point, given the extraordinarily weak track record claimants have in U.S. courts, what leverage will they have to convince present-day possessors of art to voluntarily agree to resolve claims in a commission? One can only hope that the moral suasion of the United States can someday convince present-day possessors to give up their seeming advantage and instead have claims objectively resolved on their merits.

\section{CONCLUSION}

If the Supreme Court does not correct Von Saher, then the need for Congress to enact federal legislation eliminating the statute of limitations defense in Holocaust-era art cases is acute. However, that need is unlikely to be satisfied given that Congress's attention is fixed on the country's economic crises and events in the Middle East. If states have been stripped of their ability to modify limitations periods, then museums and other presentday possessors can even more readily assert technical defenses to block any objective investigation of the merits of the claims. ${ }^{105}$ There will be very few, if any, "just and fair" resolutions in the United States anymore. The United States would be in violation of the very principles it led the world to sign in 1998. The remaining impetus to garner some justice for survivors of the "unfinished business" of the War would die, along with the remaining survivors who have waited so long to be rejoined with portraits of their loved ones and artifacts of the "degenerate" culture the Nazis sought to destroy.

\footnotetext{
102 Id. at 1035-36 (narrowly construing court's jurisdictional mandate on appeal).

103 Kingdom of Spain v. Cassirer, No. 10-786, 2011 WL 940882 (Mar. 21, 2011) (mem.).

104 Jennifer Anglim Kreder, Panel Report: Wrestling the Dead Hand of History: Perspectives on a Proposed State Department Commission on Nazi Looted Art, 1 Cultural Heritage \& ARTS Rev. 6, 6-7 (2010).

105 Jennifer Anglim Kreder, The New Battleground of Museum Ethics and Holocaust-Era Claims: Technicalities Trumping Justice of Responsible Stewardship of the Public Trust?, 88 OR. L. REV. 37, 59-75 (2009).
} 